\title{
Genoegsame voorwaardes vir buite-aardse rasiona- liteit: Filosofiese en teologiese oorwegings
}

A J Antonites

Universiteit van Pretoria

\begin{abstract}
Sufficient conditions for extraterrestrial intelligence: Philosophical and theological considerations

Sufficient conditions would include confirmation of extraterrestrial intelligence. Accordingly the SETI-projects of NASA and some universities are explained and examined. The possibility of UFO's is taken into account and evidence evaluated. In respect of philosophical considerations, the validity of inductive strategies is investigated as well as epistemological problems relating of rational communication. Theological considerations bring to the fore the imago Dei problem. It is concluded that in the light of both neccessary and sufficient conditions the issue no longer is of a scientific fiction nature but is on a firm scientific path.
\end{abstract}

\section{ONDERWEG NA GENOEGSAME VOORWAARDES VIR BUITE-AARDSE RASIONALITEIT - SETI-PROJEKTE VAN UNIVERSITEIT VAN KALI- FORNIË (BERKELEY) EN NASA}

Hierdie studie word onderneem met 'n doelbewuste soeke na evidensie van buite-aardse rasionele lewe deur wetenskap en tegnologie. Dit het reeds begin voor die ontdekking van ander planetêre stelsels (kyk Antonites 1966). Die ontdekking van laasgenoemde gee egter nou veel sterker motivering aan die soeke na evidensie van buite-aardse rasionele lewe. Dit is veral dr Frank Drake van Cornell Universiteit se nou bekende vergelyking, naamlik die Drake-vergelyking, wat deurslaggewende gewig gedra het by die motivering van $S E T I$-projekte. (SETI=Search for extra-terrestrial intelligence). Die vergelyking is:

$$
N=R \mathrm{nf}_{1} \mathrm{f}_{2} f_{3} L
$$

$\mathrm{N}=$ getal in ons galaktika (melkweg) van beskawings wat in staat is om met ander sonnestelsels te kommunikeer. Mayr voeg tweede $\mathrm{N}$ net na die = teken, naamlik die getal van sonne in 'n galaktika. Al die uitdrukkings regs van die vergelyking is faktore wat die getal $\mathrm{N}$ gaan affekteer en verminder of wegkalwe. 
$\mathrm{R}=$ koers waarteen sterre (= sonne) in die galaktika gevorm word in die tydperk toe die sonnestelsel 'gebore' is.

$\mathrm{f}=$ die gedeelte of fraksie van die getal sonne met planete.

$\mathrm{n}=$ die getal van planete per sonnestelsel met ' $\mathrm{n}$ omgewing wat geskik is vir lewe.

$\mathrm{f}_{1}=$ gedeelte van geskikte planete waarop lewe inderdaad voorkom.

$\mathrm{f}_{2}=$ gedeelte van lewe-draende planete waar rasionaliteit ontstaan het.

$\mathrm{f}_{3}=$ gedeelte van rasionele samelewings wat die vermoë en begeerte het om met ander beskawings te kommunikeer.

$\mathrm{L}=$ tyd van bestaan (lanklewendheid) van 'n tegnologiese beskawing met ' $\mathrm{n}$ kommunikatiewe toestand.

(Sullivan 1970:273-280, Mash 1993:210, 211)

Met die koms van die radioteleskoop wat natuurlike radioseine van Jupiter en sterre van baie ver afstande kan opvang, het die gedagte by sterrekundiges en ander wetenskaplikes ontstaan dat, indien tegnologiese-rasionele beskawings elders in die heelal bestaan, hulle (of sommige van hulle) 'nie-natuurlike', met ander woorde, kunsmatige of rasionele radioseine op mikrogolf, dus op kortgolf, sal uitsaai: dit voorsien 'n aantreklike middel vir tussen-sterre kommunikasie onder talle ander moontlikhede. Morrison en Cocconi kom in 1959 vir die eerste keer met die voorstel dat radio-teleskope gebruik behoort te word om moontlike kunsmatige seine op te vang. Mikrogolf energie kan ligjare van tussen-sterre gasnewels en stof deurdring en dit is ook die goedkoopste manier om elektromagnetiese straling voort te bring. Daar is verder ook baie min steurende natuurlike agtergrondgeraas. Die 1.42 gigaherz uitstraling van die waterstofatoom sou ' $n$ besondere goeie frekwensie-roep teweegbring, aangesien waterstof en die besondere tekens daarvan oraloor in die heelal voorkom (Morrison \& Cocconi 1992: 508).

Andere middele is ook voorgestel soos swaartekrag-golwe, tachione, en selfs optiese seine: 
Various forms of neutrinos, gravitinos and other 'inos' have been proposed for communications between advanced civilisations. These particles should propagate with almost no loss throughout the interstellar medium, because they possess very tiny cross-sections for interaction. But for precisely this reason they are extraordinary difficult to capture and (at least for us) to generate and modulate. If this is indeed the communication channel of choice for advanced civilizations, our search strategy must be to become more advanced ourselves because at the moment we cannot play in that league. However, there remain the possibility of using elctromagnetic radiation (photons) for long distance communication. We do so ourselves routinely, and the majority of the searches performed up to date or proposed for the near future have concentrated on photo detection.

(Tarter 1987:172, 173)

Tog meen Simmons en ander kollegas van die Universiteit van Hawaii dat 'n fundamentele fisiese proses, naamlik die verval van 'n $\mathrm{Z}$ o -bosons tot 'n neutrino en antineutrino wat slegs $10^{-21}$ sekondes duur (en so die vinnigste proses bekend in fisika is), juis ' $n$ kommunikasie medium vir buite-aardse beskawings sal kan voorsien. Dit word nie deur sterrestof belemmer of wegversprei deur geioniseerde gas in die ruimte nie. Dit sou trillings so smal soos $10-21$ sekondes oor baie duisende ligjare deur ons galakti$k a$ (melkweg) kan stuur, wat omtrent 150,000,000 ligjare groot is (met ons son wat so 28,000 ligjare van sy middelpunt is). 'n Rasionele sein sou duidelik herken kan word (Chown 1994:19).

Die daad word by die woord gevoeg wanneer Frank Drake met 'n radioteleskoop in 1959 die nuut geboude 26 meter deursnee antenne van die Nasionale Radioastronomie Sterrewag rig op die naaste twee sonne (soos ons s'n), naamlik Tau Ceti (ongeveer 11-9 ligjare van ons) en Epsilon Eridani (10.7 ligjare). Drake het ook die Jodrell Bank Sterrewag met sy meer sensitiewe apparaat vir so 'n SETI-projek genader. Die direkteur van die sterrewag, prof B Lovell, weier sy versoek op grond daarvan dat die sterrewag nie sterrekundige navorsing kan herlei tot 'sulke spekulatiewe en twyfelagtige' ondernemings nie. Vandag is dieselfde B Lowell self 'n sterk ondersteuner van SETIprojekte (Lovell 1994)!

Drake se soektog is genoem 'Projek-OZMA'. Tau Ceti het niks opgelewer nie, maar vanaf Epsilon Eridani het hy 'n baie belowende sein opgevang. Aangesien dit kortstondig was, kon dit nie gekontroleer word nie (Tarter 1987:176). Een van die redes is dat OZMA nog nie gerekenariseerd was nie. Die Universiteit van Ohio se SETI-projek het hierna ' $n$ uiters belowende sein opgevang, maar om dieselfde redes 
kon dit nie as evidensie beskou word nie. Die USSR het in 1965 selfs aangekondig dat hul inderdaad rasionele seine ontvang het van 'n tegnologiese beskawing. Dit blyk egter toe later die natuurlike seine te wees van quasar CTA 102. Jill Tarter meen tereg dat sulke 'wolf-wolf' gebeure egter nie moet lei tot skeptisisme oor en ignorering van geldige opsporings nie. (Tarter 1987:176).

Vandag het honderde miljoen dollar gerekenariseerde SETI-projekte op dreef gekom. Belowende resultate is reeds gedokumenteer wat nou opgevolg word. 'n Nuwe era van ontdekking breek aan op 12 Oktober 1992 met die 500 jarige feesviering van Columbus se ontdekking van die Amerikas, toe presies om 3uur namiddag te Arecibo in Puerto Rico, die wêreld se grootste radioteleskoop, deur die leier van NASA se span, Jill Tarter, aangeskakel is. Op dieselfde sekond is die Goldstone Opspoorstasie Radioteleskoop deur Sam Gulkis ook aangeskakel - albei (saam met nog ander radioteleskope in ander vastelande) om gekoördineerd te soek na 'kunsmatige' seine vanuit die melkweg. Hierdie 100 miljoen dollar SETI-projek is geskeduleer vir 10 jaar en ontleed alle inkomende seine deur 'n gerekenaarde sisteem van die mees gevorderdste ontwerp. Dit het die vermoë om die ganse Enclyclopedia Brittanica in een sekond te 'ken', en om drie-letter woordfrases uit te soek uit miljoene natuurlike seine per dag. Elke sekonde voer die rekenaars 106 biljoen operasies uit om die frekwensies te sorteer, en enige kanaal met oormaat energie te indekseer. Dit skakel enigiets wat 'n aardse oorsprong het uit. Arecibo fokus op die naaste 1000 sterre binne 80 miljoen ligjare van die aarde. Dit ondersoek wel relatief minder sterre ( 2 biljoen) oor minder frekwensies (1000 tot 3000 megaherz), maar dit dan met soveel groter intensiteit en sensitiwiteit.

Daar word gelet op uitstralingspatrone wat te onwaarskynlik is om natuurlik te wees. Radiosterrekundiges stel dat sulke patrone, wanneer dit evidensie word, die eerste werklike bevestiging sal wees dat buite-aardse rasionaliteit inderdaad bestaan, en dat daar ander homo fabers en homo sapientias is naas ons self. Heel waarskynlik sal dit wiskundige reekse wees, veral primêre getalle, wat nie 'n uitkoms van natuurlike seine kan wees nie. Getalle het ook die voordeel dat hul geen kodering vereis nie - al wat nodig is, is reekse van impulse wat geskei is deur kort stiltes:

The search for ETI ... thus take itself to be on the firm path of science ... strikingly more defenite than one would think it could be: even from a position of complete ignorance about what or whether ETI's actually exist, the arguments suggest fairly precise conditions for a series of prime number pulses about where to look for them. And so we scan the skies at $1420 \mathrm{MHz}$.

(Weston 1988:89) 
NASA se Ames SETI-projek toets meer as 29 miljoen kanale met 'n antenna van 70,305 meter in deursnee. NASA se JPL projek sal teen 199616 miljoene kanale toets, met ' $n$ antenna van 34 meter in deursnee en soek dit in die hele lugruim en wel op frekwensies van 1-10 gigaherz. Op 12 Oktober is die Arecibo-radioteleskoop van 305 meter aangeskakel.

Die Universiteit van Kalifornië (Berkeley), se SETI-projek toets 106 miljoen kanale onder leiding van $\mathrm{T}$ Bowyer by 1-10 gigaherz. Dit het ' $\mathrm{n}$ aanvang geneem in 1992 met 'n nuwe 4-miljoen kanaal ontvanger, genoem SERENDIP III. Dit is ook verbind met die Arecibo-antenna van 305 meter, wat ná 12 Oktober 1992 na ander frekwensies verskuif het. Kalifornië soek egter reeds sedert 1987 op 'n klein skaal. Binne een jaar is uit 30 triljoen natuurlike seine 164 nie-natuurlike seine gedokumenteer.

Ook loods die Planetêre Vereniging die MEGA-projek onder leiding van Paul Horowitz van Harvard Universiteit, Massachusetts, en toets 160 Miljoen kanale met 'n radioteleskoop van 26.30 meter deursnee op 1.4 tot 1.7 gigaherz. 'n 'Tweeling' teleskoop is ook in Buenos Aires. Een definitiewe nie-natuurlike sein is reeds gedokumenteer te midde van triljoene natuurlike seine.

Ohio-Universiteit toets vanaf 1993 op 10 miljoen kanale met die universiteit se radioteleskoop van 53 meter deursnee op 1.4-1.7 gigaherz (die antenna is so groot soos 'n rugbyveld).

\section{BEWEGING VAN BUITE-AARDSE RASIONALITEIT NA DIE AARDE? DIE VERSKYNSELS VAN VREEMDE VLIEËNDE VOORWERPE (VVV)}

VVV is meer kontroversieël as die SETI-projekte, en hieroor bestaan relatief meer skeptisisme. Carl Sagan, byvoorbeeld 'n entoesiastiese ondersteuner van SETIprojekte, is skepties oor vlieënde vreemde voorwerpe (VVV), hoewel hy die moontlikheid ooplaat. Dit is nietemin logies om te vra of besoeke van buiteaardse tegnologiese beskawings na die aarde nie moontlik sou kon wees indien hul wel bestaan nie. Indien dit bevestiging sou verkry; sou dit SETI-projekte in 'n ander lig plaas.

Daar is reeds daarop gewys (Antonites 1996:7) dat die vyftigjare gekenmerk was deur 'n vlaag van waarnemings van VVV met 'n afname daarna. Sedertdien kom dit sporadies voor oral in die wêreld (Antonites 1996:8). Dit is redelik om te verwag dat wetenskaplikes eers 'binne'-aardse logiese verklarings vir VVV sou soek. So het talle verskynings ook geblyk te wees ballonne, meteorologiese aktiwiteit, satelliete, vliegtuie, sweeftuie, massas vuurvliegies en selfs Venus wat soms baie helder kan skyn. Soms het hallusinasies ' $n$ rol gespeel. Kunstige bedrog met fotos is ook reeds vasgestel. Daar bly egter 'n beduidende persentasie van samehangende waarnemings wat 
nie op bogenoemde wyses verklaar kan word nie. Talle skeptici verbind dit nietemin met die persone self wat dit waarneem, en wel in terme van patologiese toestande, hallusinasies of vanuit 'n okkulte-verwysingsraamwerk wat dit 'verklaar'.

Dit is inderdaad so dat talle bekende verklarings in terme van VVV mettertyd ander roetine of normale wetenskaplike (T Kuhn) verklarings verkry het, byvoorbeeld:

* Op die strande van die Paaseilande in die Stille Oseaan (2,500 kilometer van sowel Suid-Amerika en Australië) staan daar vir jare onverklaarbare reuse rotsstandbeelde 30 voet hoog, en met 'n gewig van 80 ton. Die inwoners het nooit oor die tegnologie beskik om sulke reuse rotsstrukture 20 kilometers vanaf die binneland, waar dit uitgekap moes gewees het nie, te skuif. Ander beskawings in Suid-Amerika, Australië of Asië is uitgesluit, aangesien hul duisende kilometers verwyder is, en dat geen bevestiging van hul teenwoordigheid daar bestaan nie. Verklarings deur VVV het dus as ' $n$ moontlikheid al hoe sterker vir die bouwerke begin figureer. Hedendaagse ingenieurs vind dit bykans ongelooflik hoe mense sonder hedendaagse tegnologiese middele (en selfs met dit!) die standbeelde vanaf die berge, in die middel van die eiland na die strande vervoer het. Pavel Pavel van Praag in Tsjeggië en Prof Charles Love van die Verenigde State van Amerika het egter eksperimenteel aangetoon dat ' $n$ betreklike klein getal mense 'n standbeeld van 5-20 ton op houtsleë, wat weer oor silindriese houtrollers getrek word, binne 2 minute 200 voet ver kan beweeg. Maar die probleem is dat die Paaseiland letterlik geheel en al sonder bome is. Gemotiveer deur 'n bepaalde hipotese het 'n Chileense ondersoekspan in ' $n$ meer binne ' $n$ krater op die eiland plantaardige toets monsters vir mikroskopiese ontleding deur prof John Flenney van Nieu-Seeland uitgehaal. In hierdie monsters is 'n stuifmeel-monster gevind van 'n uitgestorwe palmboom. Daar is gekonkludeer dat die palms gebruik was om rollers mee te maak. Vanweë die vervoer van die beelde is die eiland mettertyd ontbos. Vulkaniese rots is ook ontdek met silindriese gate, gate wat dui op palm-rollers wat deur lawa bedek was en wat klop met die biologiese bevinding. 'n Logiese 'binne-aardse' verklaring het dié van VVV vervang.

* In die Nazca woestyn van Peru, met sy half duim reënval per jaar, is daar figure van reguit lyne wat vanaf naby die oppervlakte geen sin uitmaak nie. Slegs vanuit 'n baie hoë hoogte (vliegtuie) kan die lyne (figure, strepe en trapesoïdes) sin uitmaak as diere, ape, spinnekoppe en jakkalse. By gebrek aan ander verklarings, het 'n hipotese, naamlik dat die Nazca lyne in die verlede bedoel was om landings- 
plekke vir VVV aan te dui, byna voor die hand liggend begin lyk. Maria Reicke, 'n argeoloog, het egter meer as vier dekades van navorsing ter plaatse gewy aan 'n ander verklaring. Hoewel die spinnekop wel 'n sterrekundige betekenis het, (konstellasie van Orion) het sy gekonkludeer dat dit veel eerder 'n religieuse of sosiologiese betekenis en oorsprong het, as VVV. 'n Ander navorsingspan van die Universiteit van Calgary het intussen twee geplunderde begraafplase aldaar ontdek wat ook in verband gebring word met die figure. Verklarings deur VVV is dus ook hier deur 'binne-aardse' logiese verklarings vervang.

* Die teenoorgestelde gebeur egter soms ook: vreemde maar hoogs simmetriese sirkels en diagramme wat die afgelope twee dekades in koringlande in Brittanje verskyn het, was ewe misterieus. Twee vragmotorbestuurders het 'n tou apparaat ontwerp en aan die media verduidelik dat dit hulle was wat verantwoordelik vir die sirkels was. Daar was dus ook in hierdie geval 'n logiese 'binne-aardse' verklaring aangebied, - of so het dit gelyk. Mettertyd het dit geblyk dat hul 'verklaring' 'n grap was met oog op sensasie. Die diagramme is intensief aan omtrent sewe verskillende soorte wetenskaplike toetsings vir verklaring onderwerp - geologies, meteorologies, chemies, en andere, maar dit gaan tans alle standaard-roetine wetenskaplike verklarings te bowe. Die Franse fisikus Pierre Guerin en die astrofisikus van die Verenigde State van Amerika, Allen Hynek, het die onherhaalbare koringsirkels by wyse van konklusie (na genoemde toetse) verbind met "superior technolocal "intelligences" who "know something about the physical world that we don't know”...' (Trundle 1995:86). Intussen het die sirkels in baie ander lande naas Brittanje verskyn. Wat egter die VVV waarnemings steeds aandag laat kry het is die steekhoudendheid van die genoemde persentasie wat alle ander verklarings (soos balonne, ens) trotseer het, naamlik: 'sigaar'-moederskip en 'pierings' waarvan beskrywings onafhanklik van mekaar op verskillende plekke in die wêreld, sterk onderling ooreenstem. Die steekhoudenheid van verduidelikings sluit ook die waarneming van mensagtige wesens by beweerde landings in. Talle mense het ook al beweer dat hulle of vrywillig of meestal sonder hul medewete in die tuie vir kort periodes opgeneem is. Meestal het hulle die 'wegvoerings' in verband gebring met die oog op medies-biologiese ondersoeke. Hieromtrent kan opgemerk word dat daar tans twee skole van denke bestaan onder wetenskaplikes oor VVV-waarnemings, en veral aangaande die beweerde wegvoerings. Ons kyk kortliks daarna. 


\subsection{Waarnemings van VVV en wegvoerings 'abductions' as selfprojeksies}

Dit herinner byna aan Ludwig Feuerbach se verklaring van godsdiens as antropologiese selfprojeksies. In hierdie geval gaan dit nie oor God, nie en het die selfprojeksie 'n meer fisiologiese, sosiologiese en psigologiese inhoud. R S Laeffen sien in sy boek The UFO verdict - Examining the evidence VVV nie as 'n werklikheid nie, maar as deel van 'n sterk sosiale beweging wat basies 'n reaksie is teen die wetenskap en die rede:

Today, the voice of antiscience has gained the upperhand in many fashionable and 'educated' circles. Psychic insight is deemed superior to scientific research: the way to solve the energy crisis is to turn back the clock (to outdoor plumbing and oxcarts): and the answer to food shortages is to return to nature that is, 80 percent of the population existing at a subsistence level on primitive collective farms, using horse - drawn ploughs. It is a sad commentary on present - day educational facilities that platitudes such as these push for 'advanced' thinking.

(Shaeffer 1981:143)

Michael Persiger, neurowetenskaplike van Laurentian Universiteit te Sudbury, Ontario (Kanada), het die waarnemings, maar veral die wegvoerings, ondersoek. Hy meen dat dit wel dui op mistiese en para-normale ervarings, maar daar kan deurgaans neurologiese verklarings daarvoor gevind word. Waarnemings van VVV en wegvoeringervarings word volgens Persiger kousaal teweeggebring deur oormatige uitbarstings van elektriese aktiwiteit in die slaaplob van die brein. Mense met hoë temporale lobbe is meer vatbaar vir wegvoerervarings, waartydens hy/sy voel hul word 'ondersoek'. Persiger meen dat dit veral magnetiese velde in die aarde is wat die uitbarstings in die slaaplob veroorsaak. Die waarnemings van VVV sal derhalwe kousaal verband hou met die magnetiese effekte van seismiese aktiwiteit, voor of tydens aardbewings. Korrelasies sal dus volgens hom betreklik maklik gevind kan word tussen datums van seismiese aktiwiteit (wat lei tot uitbarstings in die brein) en waarnemings van VVV. Die verklaring van VVV is dus volledig 'n interne kwessie - waarnemers van VVV neem in werklikheid hulleself waar. Dit het volgens Persiger geen eksterne korrelaat of betekenis nie (Blackmore 1994:29-31).

\section{3 - Wegvoering en waarnemings as eksterne reël}

Hierdie skool van denke meen dat interne verklaring slegs in besondere en uitsonderlike gevalle van toepassing kan wees, maar dat dit andersins op 'n hoogs onbevestigde en 
onvolledige hipotese begrond word. Professor J E Mack, dosent aan die Mediese Fakulteit van Psigiatrie aan Harvard Universiteit en wenner van die Pullitzer-prys, het ook as skeptikus begin om persone wat wegvoerings berig, psigiatries (onder gekontroleerde omstandighede) te ondersoek. Hy was aanvanklik ook oortuig dat patologiese bewussynstoestande vir die 'wegvoerings' verantwoordelik was, en dus interessante navorsingsstof sou bied. Die resultate van sy navorsing lei egter daartoe dat hy tot 'n totale ommeswaai in sy siening kom. Hy kom tot die gevolgtrekking dat sy pasiënte nie net psigiatries baie gesond is nie, maar dat die kortstondige wegvoerings inderdaad rieël plaasgevind het. Baie klein, en vreemde metaalvoorwerpies is in pasiënte onafhanklik van mekaar gevind en wel by pasiënte op plekke duisende kilometers van mekaar. Hierdie metaalvoorwerpies is an element-analise, elektroniese mikroskopiese fotografie asook koolstofisotope analise onderwerp. Van sy navorsing sê Mack die volgende: "After working with 20 or so abductees over the past four years, it became clear to me that I was dealing with a phenomenon that could not be explained psychiatrically, yet was simply not possible within the framework of the Western scientific worldview'. Hy meen dat ons konsensus-verwysingsraamwerk van die werklikheid moontlik te beperk is, dus eensydige Cartesiaanse ontologiese parameters:

My own impression is that we may be witnessing something far more complex, namely an awkward joining of two species, engineered by an intelligence we are unable to fathom, for a purpose that serves both of our goals with difficulties for each. I base this view on the evidence presented by the abductees themselves.

(Mack 1994:203, 204).

Mack het ook nie suggesties by pasiënte, terwyl hulle onder hipnose was, geplant nie. Ander skeptici het ook begin om negatiewe sieninge oor waarnemers te verander en meen dat verreweg die meeste waarnemers gesond is (hoewel nog steeds skepties oor VVV): 'Studies of abductees have shown that they are of at least average intelligence, from a wide range of social classes, and show no particular signs of mental disturbances or pathology' (Blackmore, 1994:30) asook 'not everyone who files a UFO report is obscure or unreliable .... In fact witnesses are usually sober reliable and sincere, and often have some standing in the country' (Schorn 1981:472). Laasgenoemde sluit onder meer president Clinton van die Verenigde State van Amerika in! 


\subsection{Ander wetenskaplikes se insigte}

Die filosoof van Northern Kentucky Universiteit, $R$ Trundle, het verras met sy onlangse (1995) artikel oor VVV in die gesiene wetenskapfilosofie vaktydskrif Methodology and science. Hy sien 'n ooreenkoms tussen beskrywinge van die anatomie van wesens by VVV wat gestrand het in die vyftiger jare en die onlangse beskrywings van prof Mack.

Those who take seriously the descriptions of these beings could criticize what might be a misguided reasoning in which an 'effect' is confused with a 'cause'. Though we may be inclined to disbelieve the descriptions because they sound too much like science fiction movies such as E.T., the movies may actually be influenced by the descriptive reports. For example, the noted astrophysicist and advisor to the US Air Force 'Blue Book UFO Report', Allen Hynek, was a consultant for several movie reporters.

(Trundle 1995:85)

Tydens die koue oorlog in die vyftiger jare is alle berriggewing oor VVV 'buite sirkulasie' gestel. Dit het toentertyd onfatsoenlik geword om ernstig oor VVV te praat. In die laaste drie jaar het daar egter 'n skielike en onverwagse verskuiwing plaasgevind. Dit is veral wetenskaplikes wat begin het om soos Trundle, Lazar, Holt en Mack, VVV openlik as 'n werklikheid te aanvaar. Die vraag is nou of hierdie verskuiwing ook te danke is aan:

* Die post-moderne wêreldbeeld, of

* Sou tegnoloë en wetenskaplikes inderdaad in die vyftigerjare 'n gestrande VVV bestudeer het en was die gevolg daarvan dat VVV vliegtuigbou (o a die 'Stealth'bomwerper) beïnvloed het? Het die swye verband gehou met die koue oorlog. Ten opsigte van laasgenoemde:

The notion of such extra terrestrial knowledge touch on dramatic dimensions with the recent claim by Robert Lazar that he had conducted reverse engineering research or the technology as a staff physicist at Los Alamos goverment facility in New Mexico in the 1980's ... top secret work eventuated into research on what was an obvious extraterrestrial machine. It was a disclike craft which was 'light years' ahead of human 
technology and knowledge on physics in terms of capacities for highvelocity $180^{\circ}$ turns, bypassing speed of light limitations, apparently instantaneous starts and stops, a gravity propulsion system that distorts space around it, glowing color changes and sensations of weightlesiness in space.

(Trundle 1995)

Die fisikus van NASA. Alan Holt, maak 'n soortgelyke opmerkings. Waar Lazar beweer dat VVV ligsnelheid kan oorkom deur ruimte en tyd te verwring (voue), gee Holt toe dat 'If the speed of light is a true limit of velocity in space-time, then the potential extra-terrestrial visitor must utilize a form of transportation which transcends space and time (Holt, in Trundle 1995).

\subsection{Evaluasie}

Sou hierdie wetenskaplikes se verslae dat VVV wel geland en onder gekontroleerde omstandighede (maar streng geheim) ondersoek is, korrek wees, tesame met hul mededeling dat enkele mensagtige wesens se lyke ondersoek is en ook lewende mensagtige wesens waargeneem is, dan beteken dit reeds ' $n$ bevestiging van buite-aardse rasionaliteit. Dan hou dit in dat daar aan genoegsame voorwaardes voldoen is. 'n Kritiese vraag is egter waarom die omvang van die gekontroleerde gevalle so uiters skraal en beperk is: sou 'n landing nie binne 'n paar uur wêreldwye sensasie veroorsaak het en alom bekend geword het nie? Die wyse van landing (in betreklike isolasie) sowel as die beperkte omvang daarvan hou logies egter geen falsifikasie van die werklikheid van moontlike landings in nie. Daar mag bepaalde redes daarvoor wees. Schaeffer se argument oor die anti-wetenskapkultuur van die 'UFO movement,' wat verwys na alternatiwe tegnologieë en 'n anti-wetenskap benadering, is nie sonder probleme nie. Sy afwysing van 'n anti-wetenskap en 'n anti-tegnologie kultuur is grootliks geregverdig, want dit bestaan inderdaad. Alternatiewe tegnologie moet egter van geval tot geval beoordeel word, en kan nie deur Schaeffer deur die bank as deel van antiwetenskap beskou word nie. Dit is gewis so dat talle 'pro-VVV' wel tot 'n antiwetenskap denkwyse behoort en daar is in enkele gevalle ook ' $n$ verband met die mistisisme. Aan die ander kant is die aangeleentheid van VVV asook buite-aardse lewe seer sekerlik baie fasinerend en inderdaad misterieus. Die verskynsel het egter geen simmetriese korrelasie met anti-wetenskap of mistisisme nie. Tewens, selfs die ander uiterste is ook die geval! In die USSR was dit geen vreemde gebeure om gereeld gewag te maak (deur wetenskaplikes) dat VVV en buite-aardse rasionaliteit 'n werklik- 
heid is nie. Dit was bykans die amptelike siening van die dialektiese materialistiese filosofie van die destydse USSR wat die teenpool van enige mistisisme was.

Persiger se 'breinlob' verklaring, en dié van Mack, is 'n saak wat deur neurofisioloë en ander, beslis sal moet word. Persiger se aanslag funksioneer egter hoogstens op 'n hipotese-vlak wat dus in beginsel vatbaar moet wees vir of bevestiging of falsifikasie. Wat wel meer ooglopend is, is dat sy verbandlegging van seismiese aktiwiteit met breinlob uitbarstings en gevolglike VVV-waarnemings nie net vergesog is nie, maar reeds falsifikasies van een komponent van sy hipotese konstitueer: VVV-waarnemings is meestal onafhanklik van seismiese aktiwiteit; samelope sou dus hoogs toevallig wees. Hierteenoor is Mack se bevinding op deeglike en gekontroleerde toetse gebaseer, en dus meer as maar net 'n hipotese.

\section{FILOSOFIESE OORWEGINGS MET BETREKKING TOT BUITE-AARDSE RASIONALITEIT}

Deur argumentering tot dusver het ons aangetoon dat die moontlikheid van die bestaan van buite-aardse rasionele lewe nie meer op 'n vlak van wetenskapfiksie lê nie, maar reeds ernstig deur verskeie wetenskaplikes en wetenskapsinstellings opgeneem word. Alhoewel finale evidensie ontbreek (Frank Drake verwag finale bevestiging voor die jaar 2000), is rugsteun alreeds so sterk dat dit filosofiese en teologiese refleksie regverdig.

\subsection{Berus soeke na buite-aardse rasionaliteit nie op 'n induktiewe strategie nie?}

Die veronderstelling van hierdie vraag is dat indien die soeke wel op induksie berus, daar nog nie genoeg premisses voorhande is vir ' $n$ induktiewe konklusie nie. Gevolglik regverdig dit nie 'n soeke nie. Exobiologie en ander exowetenskappe kan nie bloot deur veralgemening van aardse ervaring konkludeer nie (Beck 1985:14). Is die soeke nie juis gebaseer op uitsluitlik groot getalle en selfs die logiese analise van getalle, sodat daar dan induktief tot ' $n$ veralgemenende gevolgtrekking gekom word nie? Bied die getalle-appèl, sowel as die veralgemening, 'n legitimering vir werklike bestaan van buite-aardse rasionele lewe en die soeke daarna?

Die appèl op getalle hou in dat dit onsinnig is om aan te neem dat ons die enigste rasionele wesens in 'n heelal met 'n honderd miljoen galaktikas is. Clarke meen dat daar min sterrekundiges is wat so 'n idee ernstig opneem. Verder is daar biljoene galaktikas, wat elk biljoene sonne bevat. In so 'n geweldige groot heelal, met sterre so getalryk soos sandkorrels, is dit moeilik om te aanvaar dat die voorwaarde vir lewe nie elders sou kon geld nie (Clarke 1973; Mash 1993; Mc Donough 1987). In teologiese taal dui dit op die oordadigheid van die skepping van God - waarom sou God so 'n 
geweldige heelal skep, maar net lewe op aarde skep? Die induktiewe argument kom kernagtig daarop neer:

\section{Die heelal bevat ontelbare getalle van sterre en planete (premisse)}

Dus rasionele lewe bestaan buite die aarde*.

Die filosoof Roy Mash het 'n probleem met so 'n argument, omdat hy meen dat hoewel die premisse baie sê, dit nie genoeg sê vir die konklusie nie - 'n verdere premisse ontbreek (Mash 1993:205). Mash is in 'n mate reg. Selfs vir die gediskrediteerde induktiewe argument is dit inderdaad nie 'n voldoende rugsteun nie. Hierbenewens meen Mash selfs dat die groot getalle 'n romantiese appel het! As verdere premisses hierteenoor wel bygevoeg sou kan word, byvoorbeeld die universaliteit van chemiese en bio-chemiese materie in die heelal, die konvergensie tese, en die ontdekking van ander sonnestelsels, dan konstitueer dit wel baie sterk rugsteun vir so 'n konklusie van buite-aardse lewe. Die punt is egter dat dit juis nie induktief hoef te wees nie! Suksesvolle teorieë en hipoteses is almal in ' $n$ mindere of meerdere mate empiries onderbepaald.

Mash meen dat die Drake vergelyking nie 'n deurslaggewende argument is as ' $n$ appèl op getalle nie: Drake begin met 'n groot getal wat deur 'filters' al hoe kleiner, maar meer realisties, word. Hoe groter die getal waarmee jy begin, hoe groter die kans dat daar na die sekwensie van breuke wat dit weggekalf het iets sal oorbly van beskawings; Die probleem is egter dat die Drake-vergelyking mank sou gaan aan 'n gebrek van wetenskaplike teorie: hiervolgens sou gegronde waardes nie toegeken kan word aan meeste van die terme nie. Gevolglik berus dit op 'n valse sin van rasionele hoop. Daar sal eers 'n meer spesifieke konsep voorsien moet word van wat hierdie toestande op ander planete is - met ander woorde, meer empiriese inhoude moet in terme van teorie ingevul word. (McMullin 1980; Tipler 1985; Mash 1993).

Dit moet toegegee word dat ten tye van Drake se opstel van die vergelyking addisionele premisses oor sekere toestande in die heelal inderdaad ontbreek het. Aan die anderkant is die logiese oortuigingskrag van die vergelyking nogtans geweldig sterk en wel, tot so 'n mate dat die SETI-projekte (reeds genoem) hierdeur gemotiveer is. Ten opsigte van die addisionele premisses kan tans vermeld word dat die sake soos vermeld in ons argument ten opsigte van die biologiese (soos Titan en die ontdekking van aminosuur-glisien), die ontdekking van ander sonnestelsels (vergelyk Beta Pictoris en

* Dit afgesien daarvan dat die induksie in die wetenskapsfilosofiese wêreld vandag gediskrediteer is.

Tog sou mens kon praat van strategieë in die wetenskap wat vergelykbaar is met induksie. 
Pulsar PSRB) inderdaad reeds 'n goeie mate van empiriese invulling bied naas die logiese konstruksie slegs vanaf die aarde. Meer spesifiek is dit ' $n$ empiriese invulling van faktor $f$ van Drake se vergelyking.

Hoewel dit nie noodwendig 'n baie sterk argument is soos deduksie nie, kan 'n induktiewe-analogie argument (anders as gewone induksie) vanaf byvoorbeeld slegs toestande op die aarde en Mars (atmosfeer, pole atmosfeer, water, stikstof, ens) somtyds baie geslaagd wees. Drake se argument sonder hedendaagse bevindinge sou derhalwe nie sonder gewig wees nie. Al sou hier 'n romantiese appèl meespeel (en waarom nie!?) is die eintlike oortuigingskrag de logies-empiriese.

Tog is dit nie heeltemal duidelik waarom teorie wel sou ontbreek by die Drakevergelyking vanweë beweerde onvolledige inligting nie. Dis ook nie duidelik met watter teoriebegrip veral Mash en McMullin in dié besondere geval mee werk nie. Gegee die Drake-vergelyking en gegee ons argumentering tot sover, dan sou 'n konklusie ten gunste van buite-aardse rasionaliteit baie goed in samehang wees met meer resente paradigma of teorie verstaan in die wetenskapsfilosofie. In besonder verwys ek na die onderbepaaldheid van teorieë (wat natuurlik nie enigiets regverdig nie), asook die konkludering tot ' $n$ teorie in terme van wetenskaplike waardes (T Kuhn).

Natuurlik het ons geen ander keuse as om te begin by die aarde nie - ons het nie die aarde toevallig gekies nie. Hier het inderdaad lewe ontwikkel. Dit waarborg egter nie dat ons geval tipies is nie. Hoe wyd gaan ons tipies rek? Selfs al sou dit korrek wees (en dit kan) om op die wyse induksie vanaf 'n enkele geval te legitimeer, mag dit volgens Mash glad nie eers van toepassing wees nie deurdat die lewe elders heel anders mag wees (Mash 1993:218). Dis egter nie duidelik hoe moontlike andersheid van lewe vir Mash die beginsel van die argument affekteer nie.

\subsubsection{Epistemologiese probleme}

Die probleemstelling hier is dié van kenbaarheid, kommunikasie, asook wetenskaplikheid, indien die situasie ten opsigte van rasionele bestaan elders, ingrypend anders is. Gevorderde tegnologiese beskawings word verbind met verstanende, kennende en begrypende aktiwiteit, en veral rasionele kommunikasie. Columbus, Dias, da Gama en Cook het in terme van Europa ook vreemde beskawings ontmoet - hulle is egter mense soos genoemdes en tale is soms verstommend goed vertaalbaar, sodat kommunikasie kan gedy: Vir alle kulture geld die denkwet van non-kontradiksie naamlik $a=b$, en $a \neq b$ kan nie albei waar wees nie, en y $x y=y^{2}$. Sal ontdekkings elders in die heelal op dieselfde dui? Indien lewensvorme ingrypend anders is, maar wel rasioneel, sal dieselfde epistemologiese kriteria geld?

As ons vorige argumente ter sake is, dan sou die volgende logies wel moontlik wees en empiries veel meer as net spekulatief. Dit sou kon wees dat buite aardse rasionele lewensvorme biologies oop sisteme is wat vrye energie gebruik om hul interne 
organisasie te vermeerder. Sodanige vorme mag skitterende lig patrone bevat, of magnetiese plasma, of mag binne soliede waterstof teen temperature skaars bo die absolute nulpunt bestaan. Hulle mag rasioneel, tegnologies en eties gevorderd wees, maar anatomies amoeba-strukture van agt ton gewig wat in skuimerige waters beweeg. Sommige meen dat die kanse gering is dat hulle 'n sentrale senustelsel soos ons sal hê (Beadle 1964).

Dis egter ook moontlik dat hulle 'n gemeenskaplike koolstof basis met ons deel, asook 'n soortgelyke sellulêre organisasie, maar hul anatomiese struktuur en vorm so anders is dat ons dit skaars kan bedink. Of hul mag wel rofweg 'n menslike of mensagtige anatomie hê en wel 'n senustelsel (Mash 1993:219).

As rasionaliteit in die eerste gevalle (amoeba-agtiges) wel duidelik sou wees, maar van 'n heel ander aard, dan sou sinvolle verstaan en kommunikasie nie buite die kwessie wees nie. In die geval van soortgelyke, senustelsels en 'n koolstofbasis mag hul wel 'n konsepsuele skema besit wat met ons s'n oorvleuel in sekere areas soos wiskunde en ander wetenskappe, maar andersins weer buite ons begrip geleë wees. By die mensagtiges mag hulle konsepsuele stelsels, wiskunde, wetenskappe, musiek, kuns, ekonomie, politiek en godsdiens wat ons s'n oorvleuel (Mash 1993:219). Ten opsigte van hierdie probleem sou mens kon opmerk (maar wat die saak verder kompliseer) dat die jongste navorsing en toetsing 'n goeie mate van rasionaliteit by diersoorte soos sjimpansees asook gorillas aandui, en nog meer by die dolfyn, waar steeds voortgaande navorsing met al hoe meer verassende insigte kom. Tog is hulle nie mense nie, maar dis 'n vergelykbare situasie, veral by die dolfyn met sy anderse anatomiese struktuur. Die veronderstelling is dat waar intra-aardse rasionaliteit by sekere diere voorkom, extraaardse (buite-aardse) rasionaliteit moontlik meer as by ons mense mag wees. Sou die mers ten opsigte van rasionaliteit 'n midde posisie inneem tussen intra en extra? Of is daar nie so iets soos intra en extra, laer, middel en hoër rasionaliteit nie, maar slegs een rasionaliteit, maar waar buite-aardse rasionaliteit meer tyd vir ontwikkeling en kreatiwiteit kon gehad het? So mag dit wees dat soos sommige meen dat hulle nie soos ons meer konstruksiewerk doen ten opsigte van riviere, damme, brûe en geboue nie, maar galaktikas rekonstrueer, herbou of selfs materie se struktuur verander. Kan ons verwag dat ' $n$ miljoenjaar oue beskawing dieselfde ingenieurswerk sal verrig as een van 'n paar duisend jaar oud soos ons s'n? (Sagan 1985)

Kan ons verwag dat, al sou hulle hoogs rasioneel en tegnologies gevorderd wees hulle wel uitstaande kreatief kan wees, maar nie in staat sal wees om tot tien te kan telnie (Osacks in Weston 1988:95)! Laat ons let op twee denkskole in dié verband.

\subsection{Denkskool van geslote aardse partikulariteit}

Die bekende filosoof $\mathrm{N}$ Rescher - meen dat buite-aardse wesens wetenskaplike oriëntasie waarskynlik iets heel anders sal wees, asook die wyse hoe hulle dit tot uitdrukking. 
bring. Hulle wiskunde kan iets heel anders wees: so sou hul rekeningkunde glad nie numcries hoef te wees nie, maar bloot vergelykend in plaas van kwantitatief. Dit veral as hulle omgewing nie gekenmerk sou wora deur soliede objekte of stabiele strukture nie. As hulle anatomie ' $n$ jellievis-struktuur het wat in skuimerige waters beweeg sou hulle meetkunde vreemd wees. Dit sou waarskynlik meer topologies en aangepas wees by strukture in plaas van groottes of vorme. Dit is denkbaar dat digitale denke in al sy vorme onderontwikkeld is, terwyl analogie-redenering hoogs ontwikkeld mag wees. Gegee dat hulle wiskundige denkpatrone anders as ons sin mag wees, mag hulle beskrywing van die fisiese natuur in wiskundige terme ook baie anders wees (Rescher 1987:85). Epistemologies gesproke sou so 'n wiskunde nie meer of minder waar wees as ons sin nie, maar slegs anders.

Hulle wetenskaplike oriëntasie sou ook andersins heel anders kon wees: hulle mag kommunikeer met 'n soort telepatie, gebaseer op varierende geure of eksotiese seine. Hulle mag 'n denkgolf oordrag deur 'n idee-draende eter ontwerp. Elektromagnetiese verskynsels wat vir ons bekend is, mag buite hulle verwysingsraamwerk geleë wees. Hulle wetenskap sou aangepas wees by die besondere patroon van hulle interaksie (ontmoeting?) met die natuur en andere. Akoustiek mag vir hulle weinig of geen betekenis hê nie.

Dit is voorstelbaar dat hulle paradigmas, hul konseptualisasies, hulle wetenskaplike wêreldbeelde iets heel anders mag wees:

We must reckon with the theoretical possibility that a remote civilization might operate with a radically different system of concepts in its cognitive dealing with nature. It is (or should be) clear that there is no single, unique ideally adequate concept framework for describing the world .... It is mere mythology to think that the 'phenomena of nature' can lead themselves to only one correct style of descriptive and explanatory exposition. There is surely no 'ideal scientific language' that has a privileged status for the characterization of reality. To insist on the ultimate uniqueness of science is to succumb to 'the myth of the Gods eye view' Different cognitive perspectives are possible - no one of which is more adequate or more correct than an other independently of the aims and purposes of their users.

(Rescher 1987:85,87)

Dit sou net soos Cicero se denkwêreld wees teenoor die wêreld van die kwantumteorie se wêreld. Die Romeine het ook nie ander visies op die besondere relatiwiteitsteorie nagehou nie - hulle had géén visies hieroor gehad nie - dit was geleë ver buite hulle konseptuele bereik. 
Volgens hierdie skool van denke sou SETI-projekte dus 'n verkwisting die geld van belastingbetalers wees. Met heel verskillende verwysingsraamwerke sou ons nie hul seine (indien dit by hul raamwerk pas) kan dekodeer en omgekeerd, hulle ons seine nie. Radio golwe is die produk van 'n aardse tegnologie, eie aan ons denkwêreld.

Hierbenewens kan gekonstateer word dat die wetenskap inderdaad nie in 'n lugleegte nie, maar altyd in ' $n$ bepaalde leefwêreld, kulturele of godsdienstige tradisie ontstaan het. Sommige filosowe reduseer egter wetenskap volledig tot sosiale aktiwiteit as sosiaal kousaal bepaald (sg 'strong'-progamme). Ander weer sien geen verband tussen die twee nie en meen dat wetenskap 'n onafhanklike logika van sy eie het. Albei partye het ' $\mathrm{n}$ punt beet: so byvoorbeeld het die gebruik dat baie wetenskappe wiskunde aanwend in beskrywings en verklarings sy oorsprong gehad in die Griekse kulturele tradisie van die kosmos as orde, asook by die godsdienstige mistiek van die Pythagoreërs.

Weston (1988) en Rescher (1987) deduseer egter hieruit die konklusie dat soortgelyke wetenskappe en kennis buite die aarde hoogs onwaarskynlik tot onmoontlik is. Die rigting wat ons fisika die afgelope twee eeue ingeslaan het, is volgens hulle geensins 'n onvermydelike, noodwendige rigting nie. Die stowwe wat beskikbaar was vir Maxwell, Michelson en Morley sou nie daar gewees het as chemie 'n ander rigting ingeslaan het nie. Radiosterrekunde is grootliks 'n newe-effek van die Tweede Wêreldoorlog en wel as gevolg van militêre druk vir die ontwikkeling van radar. Sou die oorlog anders verloop het, sou ons fisika waarskynlik anders daar uitgesien het. Die vraag is dus: moet 'n kultuur juis radio-golwe ontdek alvorens dit ander middele ontdek wat onbekend is aan ons?

Die wetenskap is volgens hierdie argument onlosmaaklik ingebed in 'n kontingente sosiale montering. Selfs al sou daar elders by vreemde beskawings soortgelyke 'seleksie voorwaardes' bestaan, dan is daar weinig rede om aan te neem dat hul enigiets vergelykbaar met ons wetenskap sou hê. Ekonomiese toestande, sosiale organisasie en kulturele aanpassing sou dieselfde aanpassing moes maak alvorens die skuif van rasionaliteit na wetenskaplike rasionaliteit bewerkstellig sou kon word. Die voorwaardes vir so ' $n$ skuif is selfs op aarde nie altyd teenwoordig waar daar rasionaliteit is nie. Wanneer hierdie sosiaal-kulturele-godsdienstige montering en noodsaaklike voorwaarde van wetenskap sou verval, ontstaan 'n vakuum - waarheen dan wetenskap? (Rescher 1987:100; Weston 1988: 92, 93).

Hieromtrent sou 'n mens kon instem dat genoemde bodem inderdaad die geval is. Dit hou egter nie in dat wetenskap gereduseer moet word tot sy montering of bodem nie. Relatiwiteit hoef nie relativisme te word nie. Anders gesê: natuurlik is die objek pool (soos in die Cartesiaanse visie) nie 'n an sich werklikheid nie, maar andersyds kan die objek pool, die nie-bewussyn, die nie-subjek, nie weg gereduseer word nie. 
Hoewel die montering kennis soos y $\mathrm{x} \mathrm{y}=\mathrm{y}^{2}$ geïnspireer het, is dit tog meer as ' $\mathrm{n}$ sosiale-konvensie. Die Pythagoriese mistiek het inderdaad die toepassing van die wiskunde moontlik gemaak, maar baie ander kulture en godsdienste sou dit vandag nie algemeen aanvaar nie. Resher en Weston se argument loop dus uit op historisme.

\subsubsection{Denkskool van universaliteit van verwysingsraamwerke}

Sagan (1985) Sklodofski en veral Minsky (1987), het op hierdie gebied veel verrig. Minsky van die Massuchets Instituut vir Tegnologie (MIT) ontken nie kulturele en ander invloede van verskillende oorsprong nie, maar redeneer dat alle rasionaliteit hier of elders in die heelal - op soortgelyke maniere behoort te werk. Sy argument is daarop gebaseer dat alle rasionele probleem-oplossers onderworpe is an dieselfde begrensing ten opsigte van ruimte, tyd en stowwe. Jy kan nie anders as om hierdie begrensing te hanteer nie en moet middele hê om dit te manipuleer.

So moet enige rasionele wese simbole-stelsels ontwerp om objekte, oorsake en doele begrypbaar te maak, maar ook die prosedures vir die doel te formuleer en te onthou. Enige rasionele wese wat op enige plek in die heelal evolueer, sal onvermydelik sekere en baie besondere idees nodig kry, byvoorbeeld oor wiskunde, kousale rede-nering en ekonomie. Hierdie besondere idees is meer eenvoudig as ander idees met soortgelyke gebruike.

Die vanselfsprekende begrip van ' $\mathrm{n}$ 'ding' is onvermydelik vir die hantering van bronne van die ruimte met sy substansies. Net so is die begrip 'doel' onvermydelik vir enige wese om tyd mee te hanteer, sowel vir dit wat ons doen en waaroor ons dink. Rasionele wesens elders in die heelal sal ongetwyfeld ook hierdie begrippe gebruik omdat dit maklik is om so evolusionêr te ontwikkel en omdat daar blykbaar geen ander maklik geëvolueerde alternatiewe bestaan nie.

Die vraag sou tog nog gevra kan word: sou vreemde beskawings bogenoemde nie tog op volledig, totaal ander maniere doen nie? Minsky meen dat hierdie probleem glad nie so arbitrêr is nie. Ons kan dus verwag dat sekere apriori-strukture elders kan ontwikkel en tewens altyd so sal wees wanneer daar berekeninge gedoen moet word en seleksies gemaak moet word uit 'n magdom van moontlike prosesse. Die idees van getal en rekenkunde is ' $n$ goeie voorbeeld hiervan: ' $\ldots$ this may be why different people can communicate so perfectly about such matters, although their minds may differ in many other ways. And so, it may apply to aliens, too' (Minsky 1987:119, 120).

Sekere sake is gewis nie arbitrêr nie: niemand kan arbitrêr sommer enige nuwe getalsisteme ontwerp wat sê maar enige getal oorslaan, byvoorbeeld vier nie. Sou iy dit wel probeer sal jy moet uitmaak wat sê $2+2$. Sou jy sê dis 5 , dan moet 5 'n gelyke getal wees en so ook 7 en 9 . Wat dan van $5+5$ ? Is dit dan 8 of 9 of 10 ? Gevolglik sal jy die eienskappe van al die ander getalle moet verander - in werklikheid het jy dan nie hul eienskappe verander nie, maar slegs die getalle se name! 
From all this, I conclude that any entity who searches through the simplest processes will soon find fragments which do not merely resemble arithmetic but are arithmetic. It is not a matter of inventiveness or imagination, only a fact about the geography of the universe of computation, a world far more constrained than that of real things.

(Minsky 1987:122).

Vreemde rasionele wesens sou ook ten opsigte van taal, vanweë soortgelyke redes, oor begrensing talle grondliggende ooreenkomste toon.

Ons kies om Minsky se konklusie te volg: Selfs groot anatomiese en fisiologiese verskille hoef nie die struktuur van rasionaliteit op te hef nie. Dit is selfs ondenkbaar.

\section{TEOLOGIESE OORWEGINGS}

Die verandering van die geosentriese paradigma na die heliosentriese paradigma was vir sowel Rooms Katolieke as Protestantse teoloë aanvanklik geheel en al onaanvaarbaar. Vir hul Skrifverstaan was dit iets wat nie mag wees nie. Die toe bestaande paradigma het eenvoudig nie sulke gegewens toegelaat nie.

Net soos die bestuiwing van wolke as 'opstand teen God se heerskappy' gesien is, is verkennings in die ruimte na onder ander planete gesien as ' $n$ 'indringing in God se domein' en 'God sal dit ook nie ongestraf toelaat nie'. So 'n siening is teologies egter moeilik verdedigbaar. Selfs al sou mense kolonies gaan vestig op die maan, Mars of Ganymede, geld die evangelie nog steeds vir hulle as sondaarmense. Die heilsgebeure te Jerusalem sal nog net so nodig wees vir ' $n$ tinmyn nedersetting op die asteroïde Ceres. Sodanige nedersettings of verkennings sou ook in samehang gesien kon word met Genesis 1:28: '... bewoon die aarde en bewerk dit ....'. Aarde sou dus 'n verruimde begrip kon word wat veel verder strek as net ons planeet.

Teologies is so ' $n$ probleem egter minimaal in vergelykinng met die probleem van rasionele lewe (en wat mensagtig mag wees of nie) buite die aarde op ander sonnestelsels. Veronderstel hul het geen godsdiens, of indien wel, nie die inhoude van die Christelike geloof nie? Hierteenoor sou kon geld dat Columbus en Da Gama dieselfde teëgekom het en dat verbintenisse tot die weg, waarheid en lewe dieselfde bly. Tog het ons hier met iets anders te doen - sou God Hom nie ook bekend gemaak het aan hulle, waar daar selfs duisende tot miljoene beskawings en kulture bestaan nie? Dit is tog 'n ander situasie as miljoene mense op aarde wat ook nog nie die evangelie verneem het nie, aangesien die miljoene mense in kontinuiteit staan met alle mense, in kontinuiteit met sonde en dus verlossing. 'n Inwoner van die binneland van Papua sou die gebeure 
in Jerusalem as 'n gebeure in die mensewêreld waarby hy betrokke, is kon sien. 'n Rasionele wese van 'n sonnestelsel in Aldebaran het om meer as een rede diskontinuïteit met die mensegeslag op aarde: histories, kultureel - en sonde?

Die verhouding geloof-wetenskaplike kennis, asook teologie-wetenskap kom opnuut dus hier ter sprake. Die belangrikste kwessie is hier in die lig van ons argumentering tot sover - die fisies-chemiese natuur in die natuurwetenskappe enersyds, en skepping asook skeppingsgeloof andersyds.

Wat uit dieselfde argumentering na vore tree as ter sake, is die evolusie teorie met die rasionaliteit as die optimum uitkoms hiervan (Kyk Antonites 1996:15). Teologies is dit nie iets nuuts nie. Hieroor is reeds veel geredeneer. Wat nuut is, is nuwe modelle van evolusie en nou veral die ontstaan van rasionele bestaanswyses buite die aarde. Hier geld ontdekkings soos aminosuur-glisien as biologiese boustene elders in die heelal, wat opnuut teologiese besinning oor skepping en die mens oproep.

Opnuut moet weer gevra word of die skepping enersyds en die fisies-chemiese, biochemiese, asook exobiologiese werklikheid of natuur andersyds, dieselfde ontologie in gedagte het. Praat hulle in waterdigte verseëlde verskillende wêrelde, of het hulle iets vir mekaar te sê?

Dis veral Genesis, die Psalms, die profete en die wysheidsliteratuur wat heelwat uitsprake maak oor die heelal en die natuur, met ander woorde die skepping.

Psalm 19, 28, 60, 29, 103 en 104 praat oor die skepping veral in verwysing na die Skepper. Die goeie aarde dui op die weldade van God. Al die genoemde psalms roep skepsele op tot lof van die Skepper. Skeppingsgeloof is 'n refleks van die verlossingsgeloof van Israel. Die Skepper is die Verlosser en Barmhartige. Psalm 8 laat geen twyfel oor die wonderbaarlike van die sterreruim en die skepping nie. Tog fokus die psalm nie op die empiriese inhoud van die skepping nie, maar die kroon van die skepping, naamlik die mens. Hy sien 'n analogie met God, naamlik denke. Daarom kan die mens antwoord op God se spreke en oproep tot die mens. Sou mens kon redeneer dat die teologies-gesproke kroon van die skepping die ekwivalent is van die fisieschemiese, bio-chemies gesproke evolusie en wel tot die optimum ontwikkeling naamlik rasionaliteit? Nou is daar sprake van rasionele, antwoordende, denkende bestaanswyses buite die mens. Geld God se oproep tot die mens in Psalm 8 ook vir hulle?

Talle psalms maak gewag van die ordelikheid in die skepping. Hierdie orde dui egter nie noodwendig op natuurwetenskaplike wetmatigheid as verklaringsmiddele nie (hoewel dit moontlik tog iets daarvan mag impliseer of daarvoor wil sê), maar die orde wil veel meer dui op die geborgenheid wat God in sy skepping heilsaam vir die mens daargestel het. Chaos-magte kan dit nie oorweldig nie. Vanuit die ontmoeting met God wil die skeppingsgeloof verdiep word. Tog vertel dit ook van onrus en die 
gevaarvolle in die skepping. Die mens wat beweeg tussen die vrede en onvrede is egter veilig vanweë die Skepper wat dit alles gemaak het. Hoe God gemaak en geskep het lê vir die psalmdigters buite die mens se begripsvermoë. Tog praat Genesis van die mens wat uit grond (klei) gemaak is deur die Skepper wat lewensasem ingeblaas het.

Vir Genesis gaan dit nie net om die orde in die skepping nie, maar veral ook oor die volgorde. Die Westerse en uiteindelik ook latere wetenskaplike liniêre tydsbesef het hier sy oorsprong. Volgorde dui op 'n stygende lyn na 'n doel: die skepping van die mens wat sy bestemming in die Skepper het, is gerig op die sabbat, die sewende dag. In die sabbat rig die Skepper hom heilsaam tot die mens: in die sabbat verneem en beleef die mens van die Skepper as die bondgenoot (verbond). Die mens is nie uitgelewer aan die magte van die noodlot nie, maar ervaar rus en vrede vanweë die Skepper. Sou die sabbat net so getransponeer kon word na rasionele bestaanswyses op 'n planeet in 'n sonnestelsel van byvoorbeeld die son Vega? Is die genoemde volgorde nie eksklusief spesifiek vir die aardse mens eksklusief bedoel nie?

Net soos Genesis 1-3 proklameer profete soos Amos ook Jahwe as Skepper. Hulle doen dit egter vanuit hulle besondere situasie, naamlik 'n herlewende geloof in en aanbidding van kreatuurlike syndes. Amos 4 en 5 (o a) wil op die skepping 'n beroep doen as middel om vertroue in God te versterk. Deutero-Jesaja wat veel gewag maak van die Skepper, Maker en Formeerder is nie geinteresserd in 'n fisies-chemiese analise van materie wat gevorm (formeer) word nie, maar in God wat in staat is tot die geveldige skepping, wat ook kan verlos en red. Skeppingsgeloof dien dus meer tot troos, heil en hoop.

In die wysheidsliteratuur is daar tog heelwat voor-wetenskaplike insigte wat te midde van die praktiese wysheid uit hul leefswêrelde voortkom. Dit is nie wetenskaplike teorie as verklaring nie, maar dit lyk tog of die Prediker in sy Hellenistiese leefwêreld ietwat meer abstrak dink. Die Prediker ervaar geen samehangsprobleem met sy skeppingsgeloof wanneer sy voorwetenskaplike waarnemings hom tot die insig bring dat die menslike en dierlike bestaansvorme dieselfde siel/gees het nie. Sy intensie is egter nie wetenskaplike teorie nie, maar die verganklikheid van menswees.

Job kom ook met talle waarnemings ten opsigte van die natuur. Hy kom tot die gevolgtrekking dat menslike wysheid nie kom by die Skepper se wysheid nie. Hy is reeds bewus van menslike tegnologiese prestasies (hoofstuk 28) wat deurdring tot die diepste van die aarde. Tans dring die mens deur in die dieptes (hoogtes) van die heelal, vergelyk die SETI-projekte. Vir Job bevat die natuur (heelal) nie ware lewenswysheid nie. Dit is verborge in God. Sowel Genesis as die Psalms sien die natuur nie net as bewonderenswaardig nie, maar toon ook iets van 'n nuuskierigheid, iets van 'n begeerte om ondersoek in te stel en meer te wete te kom. Die skeppingsgeloof van die $\mathrm{Ou}$ 
Testament het die wêreld 'verwêreldlik' en ge-ontmitologiseer: die heelal verteenwoordig nie gepersonifiseerde magte nie en is self nie goddelik nie. Die sterre is byvoorbeeld slegs 'lampe' of 'ligte' (Gen 1). Dit konstitueer aldus nie 'n versperring of belemmering vir navorsing nie.

By die wysheidsliteratuur is daar selfs sprake van pogings om die natuur se geheime te bemeester deur middel van die rede en wetenskap, hoewel dit nooit selfstandige rasionele-wetenskaplike aktiwiteit word nie (Von Rad 1965:342). In die evangelies en Pauliniese literatuur word dieselfde skeppingsgeloof behou, maar dit vind hier sy verdieping en vervulling in Jesus Christus. Die skeppingsgeloof in die Nuwe Testament verkry sy sekerheid uit die heilsgeloof, wat weer uit die ontmoeting met Christus voortspruit. Christus se verlossing het kosmiese dimensies: dit strek uit na alles wat bestaan (Filip 2:10 e a). Vanuit die heil in die opstanding van Jesus Christus word gedink oor die kosmos, oor alles wat is.

In Johannes, Efesiërs, Kolossense en die Hebreërbrief blyk dit hoe nou verbonde heilsgeloof en skeppingsgeloof is. Hy wat hoof van die kerk is, is ook hoof van die kosmos. Hy is ook kosmiese verlosser (Die heelal sug met reikhalsende verlange; vgl Rom 8). Volgens Kolosense 1:15 en 18 is Hy wat die Eersgeborene van die dode is, ook Eersgeborene van die skepping, die kosmos. In Hom wat gekruisig is en opgestaan het is nie net die skepping ten opsigte van sy begin ter sake nie, maar het alle dinge bestand.

As sodanig word die eskatologie ook belangrik. In sowel die Ou Testament as Nuwe Testament is die werklikheid steeds op weg na die toekoms. Die doel, bestemming en uiteinde is die gesigspunt waarvanuit die werklikheid besien word. As Laaste is Hy die Eerste. As Komende is Hy by die Begin en daarna. Sy toekoms is ook ten opsigte van die werklikheid en heelal nie 'n latere bykomstigheid nie, maar is werksaam deur en in alle tye. Merkbaar in die geskiedenis is dat die vervulling van elke belofte nie ' $n$ afsluiting van die geskiedenis konstitueer nie, maar bevestiging en uitbreiding van elke belofte. Dit wys heen na 'n nuwe belofte as hoogtepunt. Die mensheid, maar ook kosmos, word verstaan vanuit die doelgerigte handelinge van God in die geskiedenis.

God het nie die mens en kosmos nodig om God te wees nie. Vanweë sy soewereine besluit is Hy dit fakties, is Hy God-met-die-mens, en so ook God-met-diekosmos. God openbaar Hom in die dood en opstanding van Jesus Christus, en is so betrokke by die nood van die mens (sonde), en so ook by die nood van die kosmos. Hy is kosmies gesproke nie ' $n$ verafgeleë stomme afgod nie. Die sonde wat oorwin is maak nie van die kosmos en geskiedenis ' $n$ afgeslote dooie terrein of geïsoleerde eiland nie. Hy kan en is aan die werk en bedien Hom soms van mense wat selfs nie van Hom 
mag weet nie. Hy laat die goeie ook deurbreek as ligbakens. Die mens kan egter nie wat in kosmos of geskiedenis gebeur lynreg direk verbind met God se wil nie, of alles van Hom losmaak nie. Daarom spreek die kosmiese en geskiedenis die mens aan en is nie maar net nie. God skep nie net in die begin nie, maar skep midde in die geskiedenis (bara as skep). Die mens is dus ook deelnemer en God se medewerker aan die toekoms en nie slegs 'n spelbreker nie.

Alles hierbo gesê lewer egter moeilike probleme op vir die kwessie van buiteaardse rasionaliteit. Dit is so dat die heil in Christus kosmiese (insluitend eskatologiese) dimensies het. Kan dit sonder meer oorgedra word op rasionele wesens in galaktikas 700,000 ligjare hiervandaan? Indien wel, maak ons die heils-kosmiese struktuur nie dan te skematies nie? Die Nuwe Testament laat blyk dat die wyer kosmiese implikasies verband hou met die heilsgeskiedenis en geskidenis van die mens op aarde. Is dit sinvol om te verklaar dat alle dinge in Hom as die Opgestane bestaan en dit net so oor te dra is na rasionele wesens op byvoorbeeld 'n planeet van die son soos Aldebaran? God is Immanuel, en so met die kosmos - geld dit lynreg so vir silikaat of ammoniak gebaseerde rasionele lewe en beskawings in 'n sonnestelsel in die galaktika van Andromeda? Sou mens kon redeneer dat anatomiese struktuur irrelevant is? Christus het as mens menslike gestalte aangeneem wat aldus vir mense heilsbetekenis het. As dit so is, het die eskatologiese vervulling met sy algeheel kosmiese implikasies (waarna verwys is) ook betrekking op ander sonnestelsels met rasionele bewoners? Kan $\mathrm{Hy}$ as Komende meganies net so oorgedra word na ander galaktikas of selfs binne ons eie galaktika?

Is die teologie en natuurwetenskap univook of is dit diskontinue, verskillende waarhede? Sou rasionele lewe elders 'n verskil hieraan maak?

Uit ons argument tot sover blyk dit dat die skeppingsverhale, en ander beskouing van die skepping in die Bybel, nie nòg 'n natuurwetenskaplike paradigma bied naas andere nie. Dit bied ook nie nog 'n kosmologiese teorie naas andere om te 'glo' nie. Wanneer die Ou Testament en Nuwe Testament na die heelal kyk gaan dit nie oor fisies-chemies-biologiese data per se nie, maar oor 'n diepte dimensie: dit handel oor die sin, doel, wese en bestemming van die kosmos. Dit gaan ook nie teoretiesbegripmatig deskriptief en verklarend te werk nie, maar eerder beeldend, metafories, eksistensieel en verhalend. Die mens word nie soseer teoreties verhelder nie, maar in die hart geraak en in beweging gebring. Skeppingsgeloof dui veel meer op ' $n$ antwoord op God in die mens se lewensreis in ontmoeting en verhouding tot God. Daarom kan 'n abstrakte teorie nie uit skeppingsgeloof gededuseer word nie. "God self lê buite die reikwydte van die wetenskaplike metode. Wetenskaplike waarhede is kwalitatief onafgeslote, en dit sluit juis die kwessie van buite-aardse rasionaliteit in. Die waarheid van 
geloof is in ' $n$ ander sin miskien ook onafgeslote (Paulus: ken ten dele), maar is self rééds die objektiewe waarheid wat na die mens kom. By God is die waarheid in Jesus Christus. Hy is die Waarheid. Die Waarheid word nie paradigmaties-teoreties ontdek nie, maar kom ontmoetend na die mens. Die prediking maak dit nie eers geldig nie, maar verklaar dit reeds as geldig.

Om dus te praat van 'n plan of ontwerp van God by die antropogenese hier of elders, binne die biologie, sou per defenisie buite die reikwydte van enige wetenskap geleë wees. Geloof in God se bestemming en plan ontspring uit 'n ander bron as dié van die biochemie. Net so sou enige reduksie binne die teologie, byvoorbeeld na die instandhouding van alles wat is deur God, kon uitloop op deïsme en eensydighede wat geloof kan verarm.

Ons konkludeer: die skeppingsgeloof se inhoud is nie dieselfde as die inhoud van 'n fisies-chemies, neorofisiologiese teorie nie. Daar is ook strukturele verskille. Ook handel die skeppingsgeloof nie oor 'n heelal en wêreld ins Blue hinein of oor 'n fiktiewe aarde nie. Dit is wel dieselfde konkrete werklikheid waarna die wetenskappe ook kyk. Voor-wetenskaplik op die vlak van die leefwêreld het ons met dieselfde wêreld te doen, al gaan dié van die teologie dit ver te bowe.

Logies volg die vraag: Is dit nie weereens die teologiese ekwivalent van evolusionêre biochemiese ontstaan van lewe (en nou ook elders in die heelal), of ' $n$ teologiese perspektief op dieselfde ontologie nie? Enersyds praat Genesis nie van 'n abstrakte of fiktiewe materie (grond, klei) nie. Hy bedoel dit heel konkreet en dit lyk dus tog na 'n raakpunt. Andersyds is Genesis 2:7 nie geïnteresseerd in die aard van die materie nie, maar handel dit veel meer om te dui op die verganklikheid, eindigheid en beperktheid van geskape menswees. So gesien sou dit wel iets kon sê vir rasionele liggaamlike bestaanswyses elders. Veel moeiliker is die uitspraak dat lewe van God is. Kan dit dan evolusionêr ontstaan? Tog is die 'stoflike' ook van God. Die hedendaagse problematiek van die verhouding neurofisiologie enersyds, en bewussyn/rede/denke andersyds, sou dus moeilik met Genesis 2:7 in verband gebring kon word.

Hierbenewens is teologie ook wetenskap (te onderskeie van geloof), en kan dit nie anders as om soos ander wetenskappe ook gebruik te maak van paradigmas, teorieë en konjunkture nie. Om dus te sê dat die fisies-chemiese werklikheid iets anders as die skeppingsgeloof se geskape werklikheid is, is korrek, maar andersyds verwys dit tog na dieselfde leefwêreld. Tot ' $n$ mate is die wetenskaplike wêreld 'n sekere herbeskrywing van ons voor-wetenskaplike wêreld. Met die ou positivistiese wêreldbeeld was die demarkasie tussen natuurwetenskap en teologie veel makliker: met die onderbepaaldheid van teorieë, kwantum-teorie en die rol van die nie-waarneembare is dit vandag egter meer gekompliseerd. Bloot vanuit 'n gesonde kritiese houding sal die teologie 
ook moet vra of die siening (soos nierbo), naamlik dat skeppingsgeloof bloot net fondament vir heilsgeloof is, nie dalk te skematies uitgedruk is nie, en vandag moontlik meer genuanseerd gestel moet word nie.

As een rede hiervoor kan genoem word dat die getuies van die Ou Testament en Nuwe Testament se boodskap ten nouste verweef is met die kosmiese wêreldbeeld van daardie tyd. Genesis 'verkondig' nie 'n geosentriese wêreldbeeld wat 'geglo' moet word nie, maar wanneer dit verwys na die Skepper doen Genesis dit met verwysing na die genoemde wêreldbeeld. Dié wêreldbeeld en skeppingsgeloof is egter krities geïntegreer: Hy kyk afwysend na die mites wat verweefd was met die wêreldbeeld, soos die goddelikheid van sterre. Genesis se wêreldbeeld is een waar die son, planete en sterre om die aarde draai, waar die aarde nie rond is nie, maar 'n plat skyf is wat bo op die waters dryf. Wanneer die Ou Testament gewag maak van die waters bo én onder die aarde, of die grondveste waarop die aarde gegrond is (Psalm 104:8) is dit nie besig om metafories of poëties te praat nie. Dit is ook nie 'n naiewe vinnige waarneming wat ter sprake is nie, maar 'n beskrywings gegrond op 'n definitiewe kosmiese wêrelábeeld.

'n Verdere probleem is die uniekheid van God se spreke tot die mens op aarde of is dit nie uniek nie? Die Hebreërbrief stel dat God, nadat Hy vele kere tot die vadere gespreek het en die profete gespreek het in die laaste jare tot ons in die Seun, Jesus Christus gespreek het. Dui dit nie sterk op uniekheid nie? Kan dit sonder meer verkondig word op andere wêrelde wat algeheel diskontinue met ons wêreld is? God se handelinge met die mens vanaf die aartsvaders tot met Christus, is spesifiek aardse heilsgeskiedenis. Daar is seker geen logiese probleem ten opsigte van die waarheidsgehalte van die evangelie indien dit aan rasionele lewensvorme op 'n planeet in die sonnestelsel van Aldebaran verkondig sou word nie. Maar, maak hulle diskontinuïteit met Jerusalem en die aarde dit sinvol? Die inhoud van die evangelie lyk inderdaad uniek aards. God se liefde tot die mens is telkens 'n 'aanpassing' van die mens-aardse situasie.

Kan die gebroke verhouding van sonde by God en mens dus net so veronderstel word by ander lewensvorme? Indien hulle nie sondaars sou wees nie, sou God geen kommunikasie toelaat nie? Sou dit teologies totaal onmoontlik wees om te verwag dat God wel ook met hul op ander wyses gehandel het, en dat by 'n toekomstige ontmoeting ons teologies talle sake sal moet herbedink - dalk radikaal?

Daar is of kan ook verdere diskontinuiteit wees ongeag die groot ooreenstemming in terme van rasionaliteit met alles wat dit inhou. Uit ons argumentering in vorige gedeeltes het ons gesien dat daar moontlik geen kontinuiteit op die proteïnvlak of koolstof-vlak mag wees nie. Veronderstel 'n hoogsbeskaafde rasionele wese word ont- 
moet, wat anatomies amoeba-agtig is, 50 ton weeg en rasioneel kommunikeer deur ammoniak-gaswisseling. Sonder om enigsins ligsinnig te wil wees, sou ons kon vra: 'Jesus Christus het opgestaan uit die dode, nadat Hy die mens se sonde op Hom geneem te Golgota'. Verkondig dit nou ook aan so 'n wese - is dit sinvol? Om te redeneer dat die Heilige Gees ook hier alle diskontinuiteite kan oorbrug is seker hier ter sprake, maar dan geld dit tog net die mensegeslag? Aan die ander kant is daar wel ook kontinuiteit, ondanks anatomiese fisiologiese verskille. Albei is skepsele en nie gode nie, eindig en nie oneindig nie, rasionaliteit sal by albei tot 'n groot mate dieselfde wees (anders is dit nie rasioneel nie) - albei het in terme van 'n evolusionêre verklaringsraamwerk uit dieselfde materie ontwikkel.

'n Moontlike probleem is die imago Dei. Die mens (Gen 1:26, 27) is verteenwoordiger van God. In die Ou Testament kry mens die indruk dat die imago Dei ontologiese betekenis het en wel in terme van 'n analogia entis. Köhler meen dat die $\mathrm{Ou}$ Testament heel konkreet dink wanneer dit verwys na die mens as beeld van God: sy regop houding en wyse van loop. Verder het die ontologiese verband met die teologiese antropologie van Genesis - die fisies- psigies- geestelike eenheid van menswees as iets besonders - nie soseer ' $n$ vergelyking met ander aardse bestaansvorme nie, maar in verwysing na sy Skepper (Eichrodt 1967:125). Dit is dan na analogie van die Skepper wat as bewus-willend (Hy skep vrymagtig) verstaan word, as self-kommunikatief. Martin Buber verwys na die feit dat die mens aangesprokene is van God: die mens kan God se stem verneem en daarop antwoord; dit is 'n Ek-jy verhouding; en aldus ook 'n analogia relationis. Von Rad sien hierin juis ' $n$ analogie van rasionaliteit by God en mens.

In die Nuwe Testament is dit net Jakobus 3:9 wat aansluit by die Ou Testament se ontologiese verstaan van die beeld van die mens. Andersins kom hier ' $n$ heel nuwe en ander verstaan, maar ook verdieping van die Ou Testament-verstaan na vore: Christus is die beeld van God en die mens is beeld van Christus. Dit kan die mens wees in geloofsverhouding met Christus en in terme van 'n etiese-eksistensiële respons op God se spreke. In 2 Korintiërs blyk die beeld dan ook nie ontologies te wees nie, maar iets metafories. Die mens het dus nie 'n besondere ontologiese status nie, behalwe in geloof (Van Staden 1995:291, 299).

Indien konvergensie sou lei tot soortgelyke mensagtige rasionele wesens; en indien sekere VVV verslae korrek is met betrekking tot mensagtige wesens, dan is die vraag: sou hulle ook deel van die imago Dei wees?

Sou mens die imago in terme van analogia entis of analogia relationis verstaan, sou dit minder problematies wees. Sou dit egter verstaan word as die beeld van Christus waar geloofsverbondenheid ter sprake kom, dan word dit 'n moeiliker pro- 
bleem. Die spesifiek aardse heilshandelinge van Christus moet dan weereens corgedra word, of lynreg veronderstel word in wêrelde wat geen antropologiese of historiese kontinuïteit het met menswees wie se gestalte die ware mens, Christus, aangeneem het nie.

Daar is wel ' $n$ ander moontlike 'kontinuiteit' met menswees, en dit is die feilbaarheid en eindigheid en dus geskapenheid van die mens. Indien verslae oor strandings van VVV inderdaad korrek is, dui dit op die feilbaarheid en eindigheid van ander gestaltes van homo-sapiens.

Verwys die Ou Testament en Nuwe Testament na buite-aardse rasionaliteit? Daar word gewag gemaak van hemelwesens. Dié gebruik is metafories en dus nie relevant nie. 'n Moontlikheid is Esegiël se visioen, soos beskryf in Esegiël 1, waarin na wesens verwys word. Dit moet toegegee word dat die beskrywing van die 'voertuig' in verse 16-19 baie sterk ooreenstem met beskrywings van VVV ( $\mathrm{vgl}$ afd 2.4). Dit dra egter nie by tot ' $n$ verklaring van die visioen nie, aangesien dit in samehang met profetiese visioene as sodanig verstaan moet word.

Om to antwoord: Teologies gesproke kan en mag buite-aardse rasionele wesens nie bestaan nie, is weer ' $n$ terugval na die ou geosentriese-heliosentriese benadering. In werklikheid gaan dit die grootste uitdaging ooit wees om hierdie moontlikheid teologies en filosofies te hanteer.

\section{TEN SLOTTE}

In terme van sowel noodsaaklike as genoegsame voorwaardes, blyk dit dat die bestaan van buite-aardse rasionaliteit so 'n sterk moontlikheid is dat uiteindelike finale evidensie al hoe meer waarskynlik word. Daarom is tydige filosofiese en teologiese oorwegings hieromtrent sinvol.

\section{Literatuurverwysings}

Antonites, A J 1996. Buite-aardse rasionaliteit: Uitvlug in fantasie of grootste uitdaging ooit aan filosofie en teologie? HTS, 52/1, 5-19.

Baggot, J 1994. New light on the cold chemistry of space. New Scientist, 1 October. Beck, L W 1985. Extraterrestrial intelligent life, in Regis, E (red). Extraterrestrials. Science and alien intelligence, 3-18. Cambridge: Cambridge University Press.

Blackmore, S 1994. Alien abduction: The inside story. New Scientist, 19 November, 1994, pp 29-31.

Chown, M 1994. Do ETs phone home with neutrino's? New Scientist, 3 December 1994.

Eichrodt, W 1967. Theology of the Old Testament, Vol II. Londen: SCM Press. 
Gribbin, J 1995. Hot dark matter loses its mystery, New Scientist, 11 February 1995, pp 14-15.

Mack, J E 1994. Abduction: Human encounters with aliens. New York: Simon and Schuster.

Mash, R 1993. Big numbers and induction in the case for extraterrestrial intelligence. Philosophy of Science 60, 204-222.

McMullin, E 1980. Persons in the universe. Zygon 15, 69-89.

Minsky, M 1987. Why intelligent aliens will be intelligible, in Regis, pp 117-128.

Morrison, P 1993. Exploring planetary worlds. Oxford: Freeman.

Morrison, P \& Cocconi, G 1959. Searching for interstellar communications. Nature $184,884-886$.

Pine, R 1989. Science and the human prospect. Belmont (CA): Wadsworth.

Ratzsch, D 1988. Space travel and challenges to religion. The Monist, 71/1, 101-113.

Regis, J R E 1987. Extraterrestrials: Science and alien intelligence. Cambridge: Cambridge University Press

Rescher, N 1987. Extraterrestrial Science, in Regis pp 83-116.

Sagan, C 1985. Cosmos. New York: Ballantine Books.

Schorn, R A 1981. Extraterrestrial beings don't exist. Sky and telescope. September 1981.

Shaeffer, R 1981. The UFO verdict-examining the evidence. Buffalo: Prometheus Books.

Shawcross, W E 1984. Mystery on the desert - the Nazca lines. Sky and Telescope, September 1984, pp 198-201.

Sullivan, W 1970. We are not alone: The search for intelligent life on other worlds. Harmondsworth: Penguin Books.

Tarter, J 1987. Searching for extraterrestrials, in Regis pp 167-190.

Tipler, F J 1987. Extraterrestrial beings do not exist, in Regis pp 133-199.

Trundle, R 1995. Extraterrestrial intelligence and UFO's: Challenges to physics, metaphysics, and theology? Methodology and Science 5/28, 73-97.

Van Staden, P 1995. Image (of God) as ethical injunction: A social-scientific perspective. HTS 51/2, 279-308.

Weston, A 1988. Radio astronomy as epistemology: Some philosophical reflections on the contemporary search for extraterrestrial intelligence. The Monist 71/1, 88-100. 